\title{
Expression of three cell adhesion molecules in bladder carcinomas: correlation with pathological features
}

Agnès Mialhe, Josette Louis, Dominique Pasquier, Jean-Jacques Rambeaud and Daniel Seigneurin

\section{Analytical Cellular Pathology, Volume 13, Number 3, 1997, pp. 125-136.}

On pages 129 and 130 the Figs 1 and 2 were printed in black and white instead of full-colour as on the next two pages. 
Fig. 1. Patterns of $\alpha 2(\mathrm{~A}-\mathrm{D})$ and $\beta 4(\mathrm{E}-\mathrm{H})$ integrins in normal urothelium and bladder cancer samples. A) Membrane $\alpha 2$ immunoreactivity at cell to cell junctions in all epithelial layers of normal urothelium. B) Superficial tumour with normal $\alpha 2$ expression on cell-cell boundaries. C) Invasive carcinoma with diffuse $\alpha 2$ pattern in cytoplasm of most epithelial cells. D) Loss of $\alpha 2$ expression in superficial bladder cancer: all tumour cells were totally $\alpha 2$ chain negative. (Streptavidin-biotin-phosphatase complex method; A) and B) bars $=20 \mu \mathrm{m}, \times 500$, C) bar $=80 \mu \mathrm{m}, \times 125$ and D) bar $=$ $50 \mu \mathrm{m}, \times 200$.) E) Section of normal bladder tissue with intense and regular $\beta 4$ expression at the junction of basal cells and the lamina propria. The underlying connective tissue is negative except endothelial cells which also express the $\beta 4$ chain. F) Superficial carcinoma with normal $\beta 4$ immunoreactivity as in normal urothelium. G) and H) Tumours with loss of polarisation of the $\beta 4$ integrin: only the basal layer $(\mathrm{G})$ or also in some cases suprabasal layers $(\mathrm{H})$ were positively stained with AA3 antibody. (Indirect immunophosphatase method; E) and F) bars $=15.6 \mu \mathrm{m}, \times 640, \mathrm{G})$ bar $=20 \mu \mathrm{m}, \times 500$ and H) bar $=12.5 \mu \mathrm{m}, \times 800$.) 
Fig. 2. Immunoreactive E-cadherin expression in normal bladder and cancerous tissues. A) All epithelial cells strongly and homogeneously expressed E-cadherin at cell to cell contacts in normal urothelium. B) Preserved E-cadherin expression in superficial carcinoma. C) Invasive tumour with heterogeneous E-cadherin expression. Some cells were E-cadherin negative whereas the others were normally stained. D) Section of superficial tumour with E-cadherin cytoplasmic staining. (Streptavidin-biotin-phosphatase complex method; A) bar $=12.5 \mu \mathrm{m}, \times 800, \mathrm{~B})$ and C) bars $=50 \mu \mathrm{m}, \times 200$ and D) bar $=$ $20 \mu \mathrm{m}, \times 500$.) 


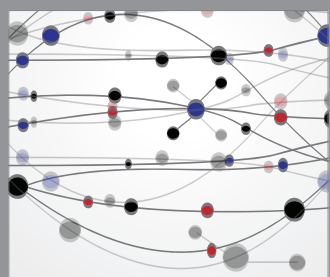

The Scientific World Journal
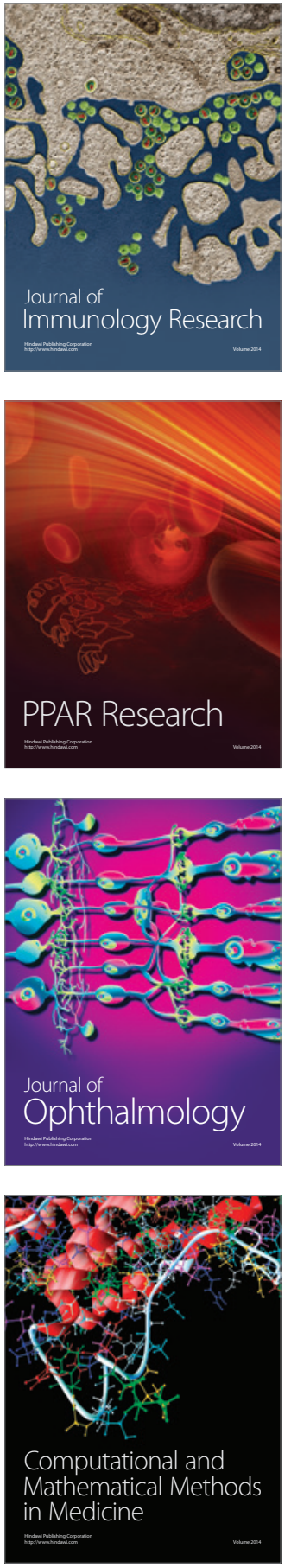

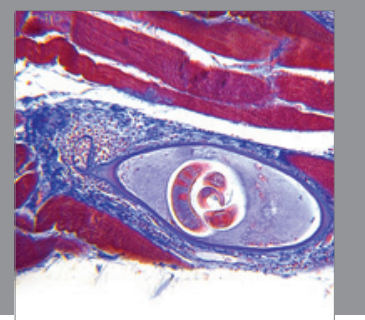

Gastroenterology

Research and Practice
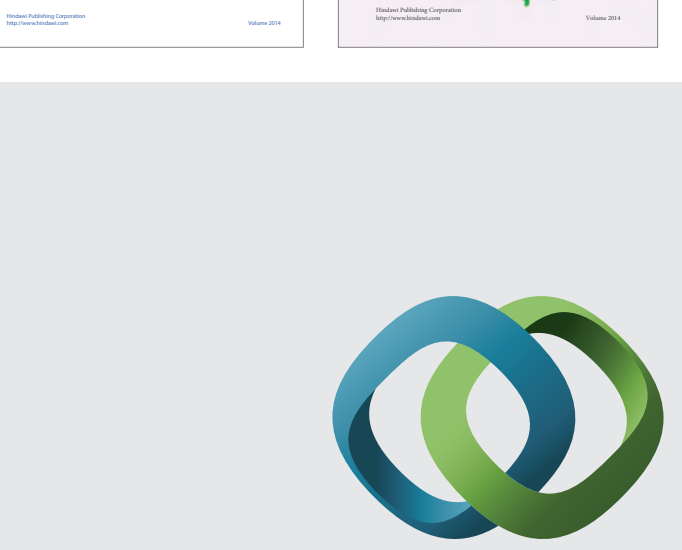

\section{Hindawi}

Submit your manuscripts at

http://www.hindawi.com


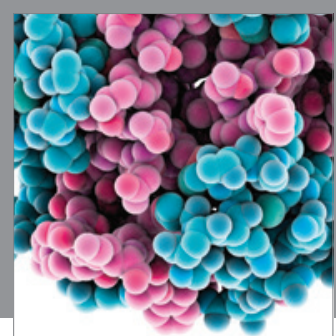

Journal of
Diabetes Research

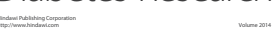

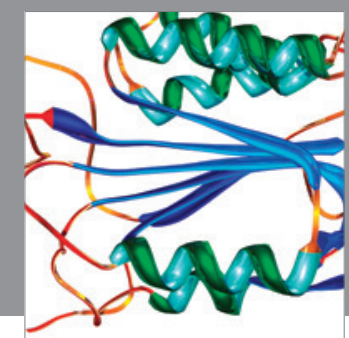

Disease Markers
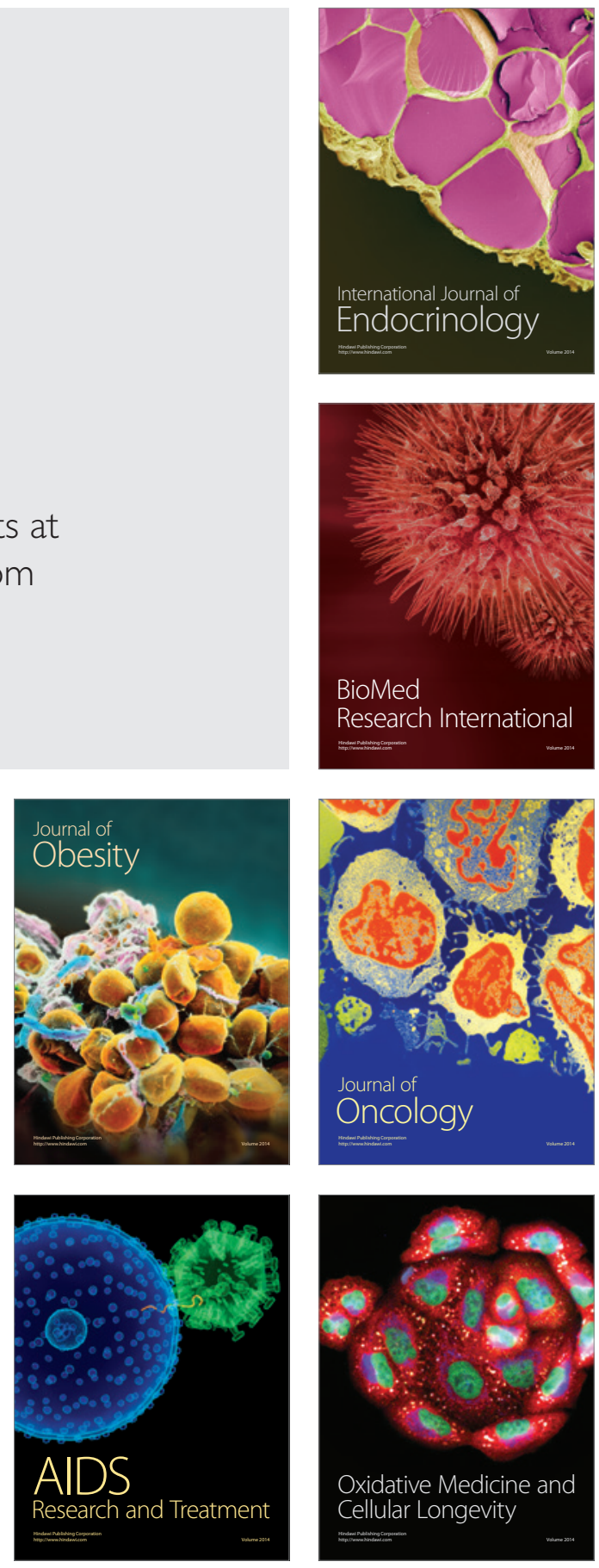